\title{
Influence of EDTA and its Association with Benzalkonium Chloride on Enterococcus faecalis Adhesion to Dentin
}

\author{
Influencia del EDTA y su Asociación con Cloruro de Benzalconio \\ en la Adhesión de Enterococcus faecalis a la Dentina
}

\author{
Pedro Cesar Gomes Titato; Rafaela Fernandes Zancan; Victor Feliz Pedrinha; \\ Flaviana Bombarda de Andrade; Rodrigo Ricci Vivan \& Marco Antonio Hungaro Duarte
}

\begin{abstract}
TITATO, P. C. G.; ZANCAN, R. F.; PEDRINHA, V. F.; ANDRADE, F. B.; VIVAN, R. R. \& DUARTE, M. A. H. Influence of EDTA and its association with benzalkonium chloride on Enterococcus faecalis adhesion to dentin. Int. J. Odontostomat., 14(4):632-638, 2020.
\end{abstract}

ABSTRACT: The aim of this in vitro study was to investigate the influence of ethylenediaminetetraacetic acid (EDTA) associated with the benzalkonium chloride (BAK) on the adhesion and formation of Enterococcus faecalis biofilms attached to coated dentin. Discs standard bovine dentin blocks were treated with the coating materials evaluated: Saline solution (control), $17 \%$ EDTA, $17 \%$ EDTA associated with $1 \%$ BAK for 5 minutes and subsequently washed with saline solution. Afterwards, biofilms of E. faecalis (ATCC 29212) were grown on the surface of coated dentin blocks for time intervals of 1 hour and 7 days $(n=20)$ and were subsequently washed with phosphate-buffered saline (PBS). Bacterial viability and total biovolume were analyzed by confocal laser scanning microscopy (CLSM) using the Live/Dead technique. Nonparametric Kruskal-Wallis followed by Dunn tests were used to determine statistical differences $(a=5 \%)$. The $17 \%$ EDTA + $1 \%$ BAK group showed significantly lower biovolume and bacterial viability values at the end of 1 hour $(p<0.05)$. After 7 days of contamination, the $17 \%$ EDTA and $17 \%$ EDTA + $1 \%$ BAK groups showed similar results that differed statistically from those of the control group $(p<0.05)$. The saline solution group showed higher values. The use of BAK associated with EDTA on dentin blocks surfaces before exposure to contamination was able to interfere in the adhesion of $E$. faecalis to dentin. Also, dentin treatment by BAK associated with a chelating agent influences the secondary biofilm formation, which could have important effects on the long-term success of root canal treatment.

KEY WORDS: benzalkonium compounds, biofilms, chelating agents, Enterococcus faecalis.

\section{INTRODUCTION}

The complete removal of microbial infection is the main purpose of root canal treatment, but this action has been considered utopian due to the complex anatomy of the intra root regions and structural organization of microbial biofilms (Nair et al., 2005; Ricucci \& Siqueira Jr., 2010; Busanello et al., 2019). Resistant endodontic microbiota consists of bacteria capable of initial adhesion to the dentin substrate, colonization and consequent biofilm development on this surface (Leonardo et al., 2002; Hancock et al., 2011; Guerreiro-Tanomaru et al., 2013). Thus, microorganisms are resistant to chemical and mechanical stresses, leading to difficulty with removing them (Peterson et al., 2015; Busanello et al.). Enterococcus faecalis (E. faecalis) is a facultative anaerobic gram-positive bacterium, often isolated in cases of persistent root canal system infections and these bacteria are easily organized in biofilm (Penas et al., 2013). From a clinical view, preventing adhesion of these bacteria to the dentin surface would be effective against persistent infections.

Biofilm formation relies on the microorganism's ability to adhere to a surface and the type of the substrate (Guerreiro-Tanomaru et al.). The substrate surface determines the film composition and microbial fixation (Hancock et al.; Guerreiro-Tanomaru et al.). To prevent bacterial adhesion to the substrate and subsequent biofilm formation, treatment of this surface has been suggested (Deng et al., 2004; Portenier et 
al., 2006; Shen et al., 2009; Pappen et al., 2010; Hancock et al.; Guerreiro-Tanomaru et al.), envisaging structural changes and permanently changing its physicochemical properties (Park et al., 2004; Jaramillo et al., 2012). When a native surface is artificially conditioned, the affinity of a microorganism to adhering to this surface may change (Jaramillo et al.).

In endodontics, different chemicals are used to interact with the intracanal dentin substrate (Zehnder, 2006). However, during the shaping and cleaning steps, some areas remain untouched by instruments and irrigation solutions (Siqueira Jr. et al., 2018). Furthermore, the mechanical action of the instruments against the canal walls results in a smear layer composed of organic remains, dentinal debris, inorganic components and microorganisms, compromising disinfection (Virdee et al., 2018). To promote complete removal of the smear layer, ethylenediaminetetraacetic acid (EDTA) solution is the chelating agent most commonly used in endodontics. It causes demineralization of inorganic components by chelating calcium ions presented in hydroxyapatite, the main inorganic dentin component (Zehnder et al., 2005; Domínguez et al., 2018). However, the disadvantages of this solution are its high surface tension (Giardino et al., 2006) and poor antimicrobial activity (Torabinejad et al., 2003) that make it desirable to perform final irrigation with an antimicrobial compound (OrdinolaZapata et al., 2012).

Benzalkonium chloride (BAK), a cationic detergent used in dentistry due to its strong antibacterial action, is commonly present in mouthwashes (Nomura et al., 2010). Its antibacterial potential depends on changes in the ionic resistance of cell membranes (Pozarowska \& Pozarowski, 2011). To the best of our knowledge, there are few studies that have reported on the effect of dentin surface treatment with EDTA associated with BAK on the adhesion of microorganisms and the eventual relations with their use for intracanal irrigation (Jaramillo et al.). Moreover, the effects of the antimicrobial activity of this solution on the formation of residual biofilms remain unclear. The present study aimed to compare the influence of root dentin surface treatment with 17 $\%$ EDTA and $17 \%$ EDTA associated with $1 \%$ BAK on the adhesion and formation of biofilm by $E$. faecalis during two evaluated time intervals. The null hypothesis tested was that the use of EDTA alone or combined with BAK would show similar bacterial viability and total biovolume values in different time intervals of bacterial adhesion.

\section{MATERIAL AND METHOD}

Sample preparation. Thirty bovine incisors with fully developed roots were selected and positioned laterally. Then, specimens of dentin discs were made according to previously used methodologies (Zancan et al., 2016, 2019). After removing the crowns at the cementoenamel junction, a trephine drill $(4 \times 4 \mathrm{~mm})$ attached to a handpiece was positioned perpendicular to these roots was used to obtain circular sections from the mesial to distal portion of the cervical and middle thirds of the roots, under abundant irrigation, yielding four dentin discs per tooth. Afterward, the disc surfaces were polished with silicon carbide abrasive paper of different granulations: 600,400 and 200 (Buehler Ltd, Lake Bluff, Illinois), coupled to a polishing machine (Fortel Indústria e Comércio Ltda., Casa Verde, São Paulo, Brazil) maintaining an average thickness of 0.8 to $1.0 \mathrm{~mm}$ of the dentin discs. Dentin blocks were clean, and the smear layer was removed by immersion in $5.25 \% \mathrm{NaOCl}$ and $6 \%$ citric acid (pH 4.0) each for 5 minutes in an ultrasonic bath. Specimens were then rinsed in sterile water for 1 minute, as seen in previous study (Jaramillo et al.). The discs were then placed in Eppendorf microtubes (Eppendorf Centrifuge 5417R, Eppendorf, Hamburg, Germany) and autoclaved at $121^{\circ} \mathrm{C}$. After this, the discs were stored in sterile saline. For coating, the discs were incubated with $5 \mathrm{~mL}$ of $17 \%$ EDTA or $17 \%$ EDTA + 1 BAK for 5 minutes at room temperature $\left(25^{\circ} \mathrm{C}\right)$. Discs incubated with phosphate-buffered saline (PBS) served as controls. After the incubation period discs were removed, gently dried, and placed in 24-well culture plates. In total, 120 dentin discs were obtained.

Dentine surface infection with $E$. faecalis biofilms. The following steps were performed under aseptic conditions within a laminar flow chamber. The bacterial strain selected for this experiment, E. faecalis ATCC (American Type Culture Collection) 29212, was reactivated in $3 \mathrm{~mL}$ of the sterile brain-heart infusion (BHI; Oxoid, Basingstoke, UK) and kept at $37^{\circ} \mathrm{C}$ for 24 hours. The purity and vitality of $E$. faecalis were confirmed by Gram staining (Oxoid, Basingstoke, UK) and electron microscopy (SMX800, Nikon Co., NY, USA) at $100 \times$ magnification. Subsequently, the culture was adjusted to $10^{7}$ cells $/ \mathrm{mL}$ by using a spectrophotometer (UV-VISIBLE, Shimadzu, Japan), at an optical density of 1 at $600 \mathrm{~nm}$ according to the 0.5 MacFarland standard. After density adjustment, the dentin surfaces were infected. 
The specimens were randomly distributed into six groups according to surface treatment and biofilm formation time intervals. For this purpose, two different time intervals were investigated: after 1 hour and after 7 days $(n=20)$. The solutions used for surface treatments were: Saline solution, 17 \% EDTA (Biodinâmica, Ibiporã, Paraná, Brazil) and 17 \% EDTA + 1 \% BAK (Bauru Formulas, Bauru, São Paulo, Brazil), purchased from commercially available sources. Dentin discs were individually placed in a 24 -well plate. All substrate samples had one of the surfaces identified with a pencil mark. The marked surface was placed facing toward the surface of the plate, and the other side was used for biofilm growth. To each well: $975 \mathrm{ml}$ of $\mathrm{BHI}+25 \mathrm{ml}$ of $E$. faecalis inoculum were added; the plates were kept in an oven at $37^{\circ} \mathrm{C}$ under aerobic conditions. To prevent nutrient deficiency, the $\mathrm{BHI}$ culture was completely replaced every 24 hours, without the addition of new microorganisms. After the growth induction periods, the samples were washed with $2 \mathrm{~mL}$ of phosphate-buffered saline (PBS) to remove nonadherent or planktonic microorganisms on the surface of the blocks.

Confocal laser scanning microscopy analysis. Afterwards, specimens were placed on a glass slab, and the biofilm layer was stained with $30 \mathrm{~mL}$ Live/ Dead reagent (Invitrogen Molecular Probes, Eugene, OR, USA). The reagent was prepared immediately before use and protected from light and heat throughout the procedures. Subsequently, they were incubated at room temperature for 10 minutes before analysis under a confocal microscope. This kit contains the green dye SYTO $8 \circledast$, which stains viable bacteria, and the red dye propidium iodide, which stains nonviable bacteria. Each sample was processed and analyzed individually.
All the substrates were examined under a confocal laser scanning microscope (Leica TCS-SPE; Leica Microsystems $\mathrm{GmbH}$, Mannheim, Germany). Four fields were observed per specimen. The images captured were then transferred to the Biolmage_L Software (Chávez de Paz, 2009). To measure the results, the parameters evaluated were bacterial viability and total biovolume.

Statistical analysis. Statistical analysis was performed by Kruskal-Wallis and Dunn nonparametric tests ( $p$ $<0.05$ ), due to the absence of normal distribution confirmed by the Shapiro-Wilk normality test. The GraphPad Prism 5.0 software (GraphPad San Diego, CA, USA) was used as an analytical tool, adopting a significance level of $5 \%$.

\section{RESULTS}

The median, minimum and maximum values of the percentage of viable cells and the total biovolume found on coated dentin blocks are given in Table I. For both analyses after 1 hour, $17 \%$ EDTA + $1 \%$ BAK showed significantly fewer viable cells when compared to the other groups $(p<0.05)$. After 7 days of contamination, the same behavior was found for $17 \%$ EDTA and $17 \%$ EDTA + $1 \%$ BAK, which differed statistically from the control group $(p<0.05)$. The total biovolume values were higher for the treated groups after seven days. Uncoated dentin blocks (control) showed higher viability and total biovolume values (Table I). Representative images of the biofilms may be visualized (Fig. 1).

Table I. Median (range), minimum and maximum (min-max) values of the percentage of viable cells and total biovolume $(\mu \mathrm{m} 3)$ after different time intervals studied, by confocal laser scanning microscopy analysis.

\begin{tabular}{lccc}
\hline \multicolumn{1}{c}{ Saline } & $17 \%$ EDTA & $17 \%$ EDTA + $1 \%$ BAK \\
\hline $\begin{array}{l}1 \text { hour } \\
\% \text { viability }\end{array}$ & $90.4^{\mathrm{A}^{*}}(80.3-98.3)$ & $90.8^{\mathrm{A}}(76.7-99.2)$ & $67.34^{\mathrm{B}}(30.8-99.4)$ \\
$\begin{array}{l}\text { Total biovolume } \\
7 \text { days }\end{array}$ & $804^{\mathrm{A}}(80.0-14626)$ & $670^{\mathrm{A}}(58-4678)$ & $134^{\mathrm{B}}(1-6346)$ \\
$\%$ viability & $79.1^{\mathrm{A}}(17.8-96.4)$ & $52.2^{\mathrm{B}}(5.34-98.0)$ & $39.18^{\mathrm{B}}(1.76-93.4)$ \\
Total biovolume & $24667^{\mathrm{A}}(774-323191)$ & $78009^{\mathrm{A}}(2042-939196)$ & $51807^{\mathrm{A}}(6779-525659)$ \\
\hline
\end{tabular}

EDTA, ethylenediaminetetraacetic acid; BAK, Benzalkonium chloride. *Different superscript letters indicate statistical differences $(p<0.05)$

\section{DISCUSSION}

Surface treatment with irrigation solutions causes changes in the physicochemical properties of dentin and consequently interferes with the process of adhesion of biofilms in secondary colonization 

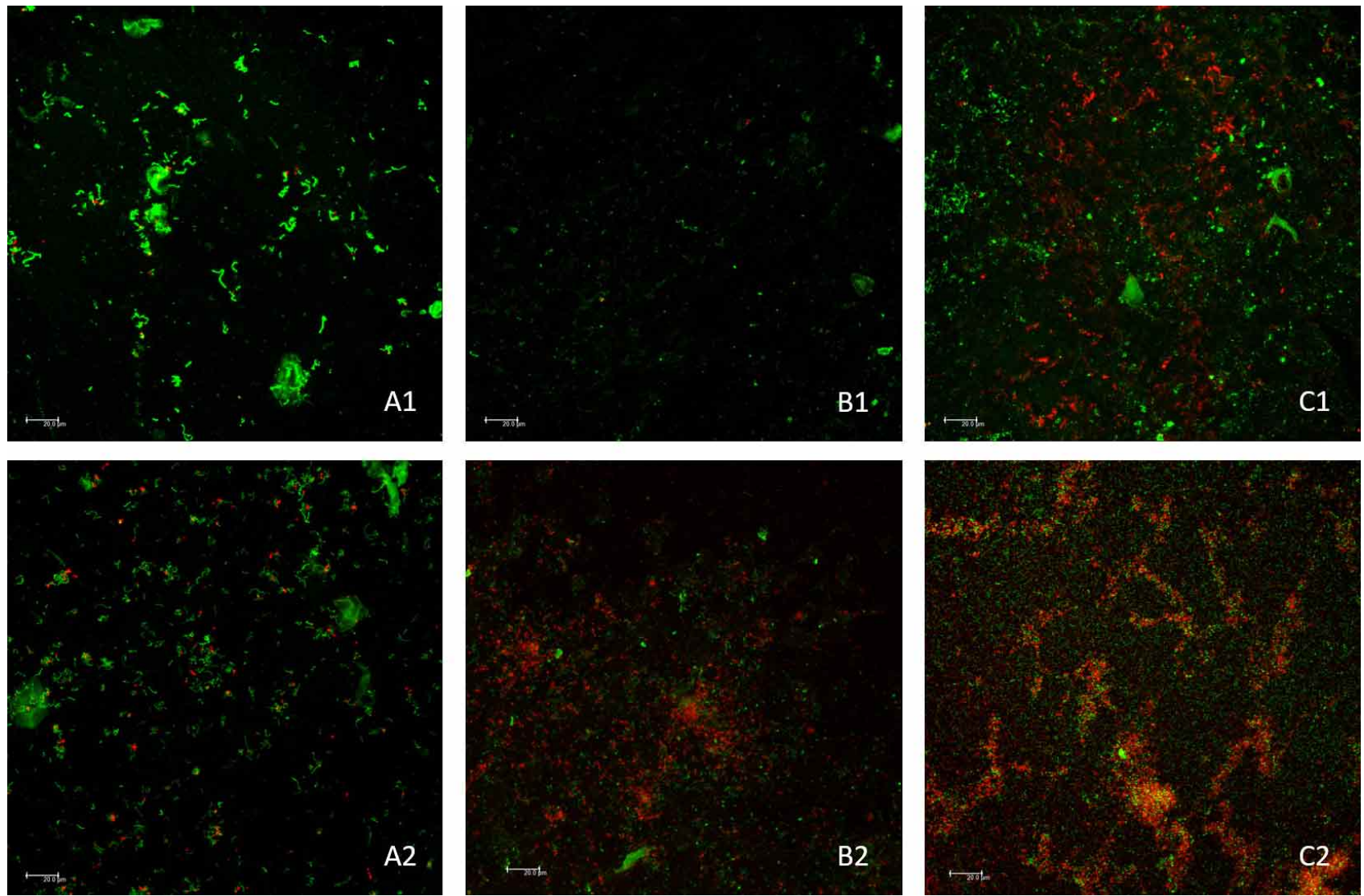

Fig. 1. Confocal laser scanning microscopy of biofilms: Saline solution (a); $17 \%$ EDTA (b); $17 \%$ EDTA + $1 \%$ BAK (c). Number 1 corresponds to biofilm formation after 1 hour and number 2 corresponds to biofilm formation after 7 days. Viable cells are seen in green, and nonviable cells, in red. Magnification: 40 x. Bars: $20.0 \mathrm{~mm}$.

(Jaramillo et al.; Ordinola-Zapata et al.; Tartari et al., 2018; Busanello et al.). E. faecalis bacteria can be found in cocci-shaped pairs or short planktonic chains, and can also be organized in biofilm structures, which increases their resistance to physicochemical stresses during root canal treatment. Furthermore, they have an affinity for alkaline environments, such as the intracanal calcium hydroxide medications used (Molander et al., 1998). In this context, E. faecalis was chosen in this study because of its ability to adapt to external factors and virulence, resulting in a high degree of pathogenicity with advantages over other microorganisms, as it has commonly been isolated in cases of failure of endodontic treatment (Pinheiro et al., 2003). In the present study, the association of 17 $\%$ EDTA with $1 \%$ BAK against bacterial adhesion was investigated in different time intervals. Given the finding of significant differences between the solutions within 1 hour, the null hypothesis was partially rejected.

With the aim of using EDTA not only as an adjunct in the root canal antisepsis process, but also in the prevention of biofilm formation, BAK was added to this solution. In the present study, when evaluating the viability and total biovolume of the specimens within seven days, no significant differences were found between $17 \%$ EDTA and $17 \%$ EDTA + 1\% BAK solution, however, the values were lower for the latter group. The reason for these results remains elusive. To the best of our knowledge, only one study evaluated the effect of dentin surface coating with BAK on biofilm formation (Jaramillo et al.). The reason for this might be related to differences in bacterial adhesive capacities or phenotypic differences among the bacterial populations. These phenotypic changes take place before adhesion and trigger inherent response factors that make bacteria immune to the surfactant's repelling action (Jaramillo et al.). From a clinical point of view, the use of this solution could be considered favorable, since the use of chelators is necessary during root canal treatment. The capability of hindering bacterial adhesion to the dentinal substrate might have important effects on the long-term success of root canal treatment when considering endodontic treatment performed in more than one session. 
The first stage of biofilm formation (phase 1) is the initial adhesion of the microorganism to a surface (seconds to minutes) (Baca et al., 2011). The interaction between the microbial agent and the substrate is mediated by the force of attraction and / or repulsion between the surfaces involved. Hydrophobic interactions between the microbial cell and the substrate are believed to contribute largely to the forces of attraction, while the repulsion forces are due to the negative net charges on the surfaces of the microbial cells and the substrate (Pieper \& Reineke, 2000). In this study, specimens treated with $17 \%$ EDTA + $1 \%$ BAK showed a lower percentage of bacterial viability and biovolume one hour after the contamination. This finding was related to the changes in the physicochemical properties of the dentin substrate caused by $17 \%$ EDTA + $1 \%$ BAK, hindering the initial bacterial adhesion process. EDTA can cause changes in dentin by modifying the $\mathrm{Ca} / \mathrm{P}$ ratio, including changes in the properties of hardness, permeability, and solubility, as well as causing dentin erosion (Cruz-Filho et al., 2011; Nogueira et al., 2018). Moreover, EDTA demineralizes the inorganic components of dentin by the chelation of calcium ions present in the hydroxyapatite, the main inorganic compound of dentin (Nogueira et al.).

In a previous study, Jaramillo et al. showed that dentin coated with $13 \%$ BAK made biofilm formation by secondary colonization more difficult than the use of $1 \%$ sodium hypochlorite (Jaramillo et al.). As in the present study, the actual mechanism of action of BAK in preventing biofilm formation has not been explored, but the influence of dentin treatments on biofilm formation when a chelating agent is used, either in combination with or without BAK have been investigated in different time intervals. BAK is an amphoteric surfactant that contains amphipathic molecules, such as quaternary nitrogen associated with a hydrophobic substituent, which are capable of reducing surface tension and increasing the surface area of hydrophobic, water-insoluble growth substrates (Pieper \& Reineke). The repulsive action of BAK might be associated with the positively charged quaternary nitrogen that interacts with the head groups of acidic phospholipids within the bacterial cell membranes. These interactions increase the surface pressure in the exposed leaflet of the membranes to decrease the adhesive potential by directly targeting the osmoregulatory and physiological functions of bacterial adhesins (Jaramillo et al.). Considering the changes in the dentin substrate caused by EDTA and the repulsive action of BAK against microorganisms, the use of these two components in a single solution contributed to making biofilm formation difficult during the initial adhesion period.

The second stage of biofilm formation (phase 2) occurs between the structures of the polymeric microbial cell surface, on which the adhesion molecules are expressed (fimbriae and pili) and the substrate (hours to days), resulting in firmer adhesion between bacteria and the substrate (Cowan et al., 1987; Miron et al., 2001). Several studies have investigated antimicrobial surface treatment and prevention of biofilm infections, and have shown promising results (Shen et al., 2010, 2011; Jaramillo et al.); however, little is known about how long the effect will last, of the antimicrobial medications commonly used to prevent secondary colonization of microorganisms. In this study, the adhesion of $E$. faecalis to EDTA-treated dentin after 1 hour showed no statistical differences in biovolume of and bacterial viability values, when compared with the control group, but over 7 days, EDTA showed favorable results for non-biofilm formation.

Regarding total biovolume, values were statistically similar for the groups with $17 \%$ EDTA and EDTA $17 \%+1 \%$ BAK surface treatment after seven days. Although EDTA has the capacity for killing microorganisms, this solution is a weak acid. With proper application time, EDTA could promote smear layer removal without eliminating the microorganisms (de Andrade et al., 2015). This could be related to our results, because the coated dentin blocks were exposed to solutions for a short time. In addition to their cleaning ability, chelating agents may detach biofilms adhering to the root canal walls, but it has been demonstrated that their antiseptic capacity is relatively limited (Zehnder; de Andrade et al.). A previous intratubular study verified the influence of superficial EDTA application and found no influence on bacterial viability (de Andrade et al.). A possible explanation for this result could be that the solutions acted only on superficial tissue of the dentin blocks and modified the substrates. Furthermore, the chelating effect on dentin mineral components can affect the metabolism of bacterial cells (Chávez de Paz et al., 2010), demonstrating that this chelator (EDTA) was bacteriostatic in nature, thereby hindering cell viability.

\section{CONCLUSIONS}

Considering the in vitro nature of this study, dentin surface treatment may reduce bacterial viability 
and biovolume in cases of secondary colonization. The $17 \%$ EDTA + $1 \%$ BAK solution had better repellent action against $E$. faecalis colonization. Considering the lack of scientific references on the subject, the need is emphasized, for further studies on this association of solutions and its effects on physicochemical properties of the dentin substrate.

\section{ACKNOWLEDGEMENTS}

The authors thank The São Paulo Research Foundation for supporting this study.

TITATO, P. C. G.; ZANCAN, R. F.; PEDRINHA, V. F.; ANDRADE, F. B.; VIVAN, R. R. \& DUARTE, M. A. H. Influencia del EDTA y su asociación con cloruro de benzalconio en la adhesión de Enterococcus faecalis a la dentina. Int. J. Odontostomat., 14(4):632-638, 2020.

RESUMEN: El objetivo del estudio consistió en investigar in vitro, la influencia del ácido etilendiaminotetraacético (EDTA) con cloruro de benzalconio (BAK) en la adhesión y formación de biopelículas de Enterococcus faecalis a la dentina. Discos de dentina bovina fueron tratadas con solución salina (control), $17 \%$ de EDTA, 17 $\%$ de EDTA asociado con $1 \%$ de BAK durante 5 minutos y lavadas con solución salina. Las biopelículas de $E$. faecalis (ATCC 29212) se cultivaron sobre los discos de dentina durante intervalos de tiempo de 1 hora y 7 días $(n=20)$, lavados con solución salina tamponada con fosfato (PBS). La viabilidad bacteriana y el biovolumen total se analizaron mediante microscopía de barrido por láser (CLSM) utilizando la técnica Live / Dead. Se realizó prueba no paramétrica de Kruskal-Wallis, seguida por Dunn con una diferencia estadística $(a=5 \%)$. El grupo de $17 \%$ EDTA + $1 \%$ BAK mostró valores significativamente menores de biovolumen y viabilidad bacteriana al final de 1 hora $(p<0,05)$. Después de 7 días de contaminación, los grupos de $17 \%$ EDTA y $17 \%$ EDTA + $1 \%$ BAK mostraron resultados similares que diferían estadísticamente del grupo control $(p<0,05)$. La solución salina mostró valores más altos. La asociación de BAK con EDTA antes de la contaminación interfirió en la adhesión de E. faecalis. Además, el tratamiento de la dentina por BAK asociado con EDTA influye en la formación de biopelículas secundarias, lo que podría tener efectos importantes sobre el éxito a largo plazo del tratamiento del conducto radicular.

PALABRAS CLAVE: compuestos de benzalconio, biopelículas, agentes quelantes, Enterococcus faecalis.

\section{REFERENCES}

Baca, P.; Junco, P.; Arias-Moliz, M. T.; González-Rodríguez, M. P. \& Ferrer-Luque, C. M. Residual and antimicrobial activity of final irrigation protocols on Enterococcus faecalis biofilm in dentin. $J$. Endod., 37(3):363-6, 2011.

Busanello, F. H.; Petridis, X.; So, M. V. R.; Dijkstra, R. J. B.; Sharma, P. K.; \& van der Sluis, L. W. M. Chemical biofilm removal capacity of endodontic irrigants as a function of biofilm structure: optical coherence tomography, confocal microscopy and viscoelasticity determination as integrated assessment tools. Int. Endod. J., 52(4):461-74, 2019.

Chávez de Paz, L. E. Image analysis software based on color segmentation for characterization of viability and physiological activity of biofilms. Appl. Environ. Microbiol., 75(6):1734-9, 2009.

Chávez de Paz, L. E.; Bergenholtz, G. \& Svensäter, G. The effects of antimicrobials on endodontic biofilm bacteria. J. Endod., 36(1):70-7, 2010

Cowan, M. M.; Taylor, K. G. \& Doyle, R. J. Energetics of the initial phase of adhesion of Streptococcus sanguis to hydroxylapatite. J. Bacteriol., 169(7):2995-3000, 1987.

Cruz-Filho, A. M.; Sousa-Neto, M. D.; Savioli, R. N.; Silva, R. G.; Vansan, L. P. \& Pécora, J. D. Effect of chelating solutions on the microhardness of root canal lumen dentin. J. Endod., 37(3):35862, 2011.

de Andrade, F. B.; Arias, M. P. C.; Maliza, A. G. A.; Duarte, M. A. H.; Graeff, M. S. Z.; Amoroso-Silva, P. A.; Midena, R. Z. \& Gomes de Moraes, I. A new improved protocol for in vitro intratubular dentinal bacterial contamination for antimicrobial endodontic tests: standardization and validation by confocal laser scanning microscopy. J. Appl. Oral. Sci., 23(6):591-8, 2015.

Deng, D. M.; Buijs, M. J. \& Ten Cate, J. M. The effects of substratum on the $\mathrm{pH}$ response of Streptococcus mutans biofilms and on the susceptibility to $0.2 \%$ chlorhexidine. Eur. J. Oral. Sci., 112(1):42-7, 2004.

Domínguez, M. C. L.; Pedrinha, V. F.; da Silva, L. C. O. A.; Ribeiro, M. E. S.; Loretto, S. C. \& Rodrigues, P. A. Effects of different irrigation solutions on root fracture resistance: an in vitro study. Iran. Endod. J., 13(3):367-72, 2018.

Giardino, L.; Ambu, E.; Becce, C.; Rimondini, L. \& Morra, M. Surface tension comparison of four common root canal irrigants and two new irrigants containing antibiotic. J. Endod., 32(11):1091-3, 2006.

Guerreiro-Tanomaru, J. M.; de Faria-Júnior, N. B.; Duarte, M. A. H.; Ordinola-Zapata, R.; Graeff, M. S. Z. \& Tanomaru-Filho, M. Comparative analysis of Enterococcus faecalis biofilm formation on different substrates. J. Endod., 39(3):346-50, 2013.

Hancock, V.; Witsø, I. L. \& Klemm, P. Biofilm formation as a function of adhesin, growth medium, substratum and strain type. Int. J. Med. Microbiol., 301(7):570-6, 2011.

Jaramillo, D. E.; Arriola, A.; Safavi, K. \& Chávez de Paz, L. E. Decreased bacterial adherence and biofilm growth on surfaces coated with a solution of benzalkonium chloride. J. Endod., 38(6):821-5, 2012.

Leonardo, M. R.; Rossi, M. A.; Silva, L. A.; Ito, I. Y. \& Bonifácio, K. C. EM evaluation of bacterial biofilm and microorganisms on the apical external root surface of human teeth. J. Endod., 28(12):815-8, 2002.

Miron, J.; Ben-Ghedalia, D. \& Morrison, M. Invited review: adhesion mechanisms of rumen cellulolytic bacteria. J. Dairy Sci., 84(6):1294-309, 2001.

Molander, A.; Reit, C.; Dahlén, G. \& Kvist, T. Microbiological status of root-filled teeth with apical periodontitis. Int. Endod. J., 31(1):17, 1998. 
Nair, P. N. R.; Henry, S.; Cano, V. \& Vera, J. Microbial status of apical root canal system of human mandibular first molars with primary apical periodontitis after "one-visit" endodontic treatment. Oral Surg. Oral Med. Oral Pathol. Oral Radiol. Endod., 99(2):231$52,2005$.

Nogueira, B. M. L.; Pereira, T. I. C.; Pedrinha, V. F. \& Rodrigues, P. A. Effects of different irrigation solutions and protocols on mineral content and ultrastructure of root canal dentine. Iran. Endod. J., 13(2):209-15, 2018.

Nomura, Y.; Bhawal, U. K.; Nishikiori, R.; Sawajiri, M.; Maeda, T. \& Okazaki, M. Effects of high-dose major components in oral disinfectants on the cell cycle and apoptosis in primary human gingival fibroblasts in vitro. Dent. Mater. J., 29(1):75-83, 2010.

Ordinola-Zapata, R.; Bramante, C. M.; Cavenago, B.; Graeff, M. S. Z.; Gomes de Moraes, I.; Marciano, M. \& Duarte, M. A. H. Antimicrobial effect of endodontic solutions used as final irrigants on a dentine biofilm model. Int. Endod. J., 45(2):162-8, 2012.

Pappen, F. G.; Shen, Y.; Qian, W.; Leonardo, M. R.; Giardino, L. \& Haapasalo, M. In vitro antibacterial action of Tetraclean, MTAD and five experimental irrigation solutions. Int. Endod. J., 43(6):528-35, 2010.

Park, Y.; Park, S. N.; Park, S. C.; Park, J. Y.; Park, Y. H.; Hahm, J. S. \& Hahm, K. S. Antibiotic activity and synergistic effect of antimicrobial peptide against pathogens from a patient with gallstones. Biochem. Biophys. Res. Commun., 321(3):631-7, 2004.

Penas, P. P.; Mayer, M. P. A.; Gomes, B. P. F. A.; Endo, M.; Pignatari, A. C. C.; Bauab, K. C. \& Pinheiro, E. T. Analysis of genetic lineages and their correlation with virulence genes in Enterococcus faecalis clinical isolates from root canal and systemic infections. J. Endod., 39(7):858-64, 2013.

Peterson, B. W.; He, Y.; Ren, Y; Zerdoum, A.; Libera, M. R.; Sharma, P. K.; van Winkelhoff, A. J.; Neut, D.; Stoodley, P.; van der Mei, $\mathrm{H}$. C.; et al. Viscoelasticity of biofilms and their recalcitrance to mechanical and chemical challenges. FEMS Microbiol. Rev., 39(2):234-45, 2015.

Pieper, D. H. \& Reineke, W. Engineering bacteria for bioremediation. Curr. Opin. Biotechnol., 11(3):262-70, 2000.

Pinheiro, E. T.; Gomes, B. P. F. A.; Ferraz, C. C. R.; Sousa, E. L. R.; Teixeira, F. B. \& Souza-Filho, F. J. Microorganisms from canals of root-filled teeth with periapical lesions. Int. Endod. J., 36(1):111, 2003.

Portenier, I.; Waltimo, T.; Ørstavik, D. \& Haapasalo, M. Killing of Enterococcus faecalis by MTAD and chlorhexidine digluconate with or without cetrimide in the presence or absence of dentine powder or BSA. J. Endod., 32(2):138-41, 2006.

Pozarowska, D. \& Pozarowski, P. Benzalkonium chloride (BAK) induces apoptosis or necrosis, but has no major influence on the cell cycle of Jurkat cells. Folia Histochem. Cytobiol., 49(2):22530, 2011.

Ricucci, D. \& Siqueira Jr., J. F. Biofilms and apical periodontitis: study of prevalence and association with clinical and histopathologic findings. J. Endod., 36(8):1277-88, 2010.

Shen, Y.; Qian, W.; Chung, C.; Olsen, I. \& Haapasalo, M. Evaluation of the effect of two chlorhexidine preparations on biofilm bacteria in vitro: a three-dimensional quantitative analysis. J. Endod., 35(7):981-5, 2009.

Shen, Y.; Stojicic, S. \& Haapasalo, M. Antimicrobial efficacy of chlorhexidine against bacteria in biofilms at different stages of development. J. Endod., 37(5):657-61, 2011.

Shen, Y.; Stojicic, S.; Qian, W.; Olsen, I. \& Haapasalo, M. The synergistic antimicrobial effect by mechanical agitation and two chlorhexidine preparations on biofilm bacteria. J. Endod., 36(1):100-4, 2010.

Siqueira Jr., J. F.; Perez, A. R.; Marceliano-Alves, M. F.; Provenzano, J. C.; Silva, S. G.; Pires, F. R.; Vieira, G. C. S.; Rôças, I. N. \&
Alves, F. R. F. What happens to unprepared root canal walls: a correlative analysis using micro-computed tomography and histology/scanning electron microscopy. Int. Endod. J., 51(5):5018, 2018.

Tartari, T.; Bachmann, L.; Zancan, R. F.; Vivan, R. R.; Duarte, M. A. H. \& Bramante, C. M. Analysis of the effects of several decalcifying agents alone and in combination with sodium hypochlorite on the chemical composition of dentine. Int. Endod. J., 51(S1):e42-e54, 2018.

Torabinejad, M.; Khademi, A. A.; Babagoli, J.; Cho, Y.; Johnson, W. B.; Bozhilov, K.; Kim, J. \& Shabahang, S. A new solution for the removal of the smear layer. J. Endod., 29(3):170-5, 2003.

Virdee, S. S.; Seymour, D. W.; Farnell, D.; Bhamra, G. \& Bhakta, S. Efficacy of irrigant activation techniques in removing intracanal smear layer and debris from mature permanent teeth: a systematic review and meta-analysis. Int. Endod. J., 51(6):60521,2018

Zancan, R. F.; Calefi, P. H. S.; Borges, M. M. B.; Lopes, M. R. M.; de Andrade, F. B.; Vivan, R. R. \& Duarte, M. A. H. Antimicrobial activity of intracanal medications against both Enterococcus faecalis and Candida albicans biofilm. Microsc. Res. Tech., 82(5):494-500, 2019.

Zancan, R. F.; Vivan, R. R.; Milanda Lopes, M. R.; Weckwerth, P. H.; de Andrade, F. B.; Ponce, J. B. \& Duarte, M. A. H. Antimicrobial activity and physicochemical properties of calcium hydroxide pastes used as intracanal medication. J. Endod., 42(12):18228, 2016.

Zehnder, M. Root canal irrigants. J. Endod., 32(5):389-98, 2006.

Zehnder, M.; Schmidlin, P.; Sener, B. \& Waltimo, T. Chelation in root canal therapy reconsidered. J. Endod., 31(11):817-20, 2005.

Corresponding author:

Pedro Cesar Gomes Titato, DDS, MSc

Bauru School of Dentistry

University of São Paulo, Operative Dentistry

Endodontics and Dental Materials

Al. Octávio Pinheiro Brisola n. 9-75

17012-901, Bauru

São Paulo

BRAZIL

E-mail: pedro.titato@usp.br

ORCID: https://orcid.org/0000-0003-2091-585X

Received: 11-03-2020

Accepted: 08-05-2020 